\title{
NAMING AND AFFECT. ONTOLOGICAL FUNCTION OF IDEOLOGY IN THE SCHOOL OF ESSEX'S DISCOURSE THEORY
}

\author{
Rafal Smoczynski*
}

\begin{abstract}
This paper maps the ontological function of affect and performativity as articulated in the School of Essex's discourse theory, most notably in Ernesto Laclau and Chantal Mouffe's writings. Firstly, it will be demonstrated that isolated agency of ideological performativity, does not involve sufficient power to introduce a coherent ontological consistency of both subject and object. Only the intertwine of libidinal force with naming, as the recent development of the School of Essex theory suggests, provides the sufficient conditions of the possibility of generating solid social ontology.
\end{abstract}

Keywords: Laclau. Mouffe. Affect. Performativity. Social ontology. Hegemony.

\section{Entering the problem}

This article maps the ontological function of ideology as articulated in the School of Essex's discourse theory, most notably in Ernesto Laclau and Chantal Mouffe's writings. Firstly, it attempts to reconstruct the School's argument on the role of the ideological interpellation, understood as a an effect of méconnaisance for the constitution of subject embedded in the intersubjective network, secondly, it will be demonstrated that isolated agency of ideological performativity, does not involve sufficient power to introduce a coherent ontological consistency of both subject and object. In order to avoid discursive idealism, the crucial dynamics of affect in shaping symbolic order has been emphasized in the recent developments of

* Pesquisador da Academia Polonesa de Ciências, Varsóvia, Polônia.

E-mail: rafalsmoczynski@yahoo.com 
the Essex School's ontological scholarship. Only the intertwine of libidinal force with naming, as this elaboration suggests, provides the sufficient conditions of the possibility of generating the intersubjective network.

\section{Field of language differences}

The pivotal aspect of the School of Essex's theory was shaped in line with the contemporary semiology which is marked with the seminal work of Ferdinand de Saussure (2002: 91-92) stating that field of language comprises merely negative differences. According to this concept the meaning of the word is not determined by its inherent content but by the external system of differences. Consequently, the fixing of the structure of meaning is possible when linguistic elements compose a field in which every single act conferring significance is embedded in the entire system of signs. This classical assumption was later reformulated by Hjelmslev (1975) who while defining principles of formal semiology has separated the rigid isomorphic relation between signifier and signified. This reworking of the original model gave rise to the development of ontological implications for semiology. Since this new turn semiology assumes that the truth of the language field applies also to any field of significance, including social field (LACLAU 2005, p. 68).

As a result of combining Saussurian heritage with post-Marxist currents of thought, Derridian deconstruction (Il n'y a pas de hors-texte), late Wittgensteinian notion of language games, and finally Lacanian radicalization of the sign ("there is only chain of signifiers") theorists from the Essex School have elaborated their theoretical stance in which the category of discourse is not limited in a narrow sense to acts of speech but is extended to any meaningful elements of the intersubjective field (LACLAU 2000, p. X). Discourse is defined as a practice of articulation, which is instituting a given meaning for the subjects and objects.

Our analysis rejects the distinction between discursive and nondiscursive practices. It affirms: a) that every object is constituted as an object of discourse, insofar as no object is given outside every discursive condition of emergence; and b) that any distinction 
between what are usually called the linguistic and behavioral aspects of a social practice, is either an incorrect distinction or ought to find its place as a differentiation within the social production of meaning, which structured under the form of discursive totalities (LACLAU; MOUFFE, 1985, p. 107).

Further on, following a Wittgensteinian approach, which states that language games comprise both linguistic exchanges and actions in which they are embedded, Laclau $(2005$, p. 13) asserted that discourse analysis should not separate articulations from the performances carried out by the subjects. The objective of the analysis should rather be concentrated on the discursive frameworks through which subjects are realizing their strategic goals. Thus, what is particularly important to describe the functioning of ideological agency, discourse does not merely reflect objects and relations pre-existing in the meaningful field, but constructs relations, identities of the objects and constructs ideological structures that are capable of interpellating subjects (HOWARTH, 2000).

The primacy of the mediating language does not, however, introduces any skepticism about the existence of the material world. Laclau and Mouffe explained this point in often quoted passage:

The fact that every object is constituted as an object of discourse has nothing to do with whether there is a world external to thought, or with the realism/idealism opposition. An earthquake or the falling of a brick is an event that certainly exists, in the sense that it occurs here and now, independently of my will. But whether their specificity as objects is constructed in terms of "natural phenomena" or "expressions of the wrath of God", depends upon the structuring of a discursive field. What is denied is not that such objects exist externally to thought, but the rather different assertion that they could constitute themselves as objects outside any discursive condition of emergence (LACLAU; MOUFFE, 1985, p. 108).

For the Essex School semiological perspective that serves as a framework of theoretical formulations should be generally understood as a social ontological project that was highly inspired by the post-foundational 
thought emphasizing the lack of ultimate ground in the social field. This theory should be thus situated in the current of the contemporary academic debate, which recognizes the "undecidability" in the field of language differences (DERRIDA, 1994, p. 247), or following Heidegerrian ontology identifies the absence of "an ultimate ground" in social, which might provide the legitimacy for subject positions, and consequently, it is impossible also to delimit any external agency that might guarantee the ontological consistency of the symbolic order. This approach could be named after Marchart (2007, p. 2). as an attempt to weaken ontological status of such metaphysical figures as the ground:

The ontological weakening of ground does not lead to the assumption of the total absence of all grounds, but rather to the assumption of the impossibility of a final ground, which is something completely different as it implies an increased awareness of, on the one hand, contingency and, on the other, the political as the moment of partial and always, in the last instance, unsuccessful grounding (MARCHART, 2007, P. 2).

Thus, Laclau and Mouffe (1985, p. 98) following Althusser's notion on overdetermination of social (ALTHUSSER, 1969, p. 203-206), claim that social relations are deprived of the ultimate literality and it is impossible to reduce them to the moments of their necessary immanence.

There are not two planes, one of essences and the other of appearances, since there is no possibility of fixing an ultimate literal sense for which the symbolic would be a second and derived plane of signification (LACLAU; MOUFFE, 1985, p. 98).

For this reason, Laclau and Mouffe state that social field does not possess any immanent essence that would precede its relational shape structured as in the de Saussurean model of negative differences: any structure of meaning that accompany its establishment is arbitrarily constituted, and its precarious position is not guaranteed by any transcendental instance. 
But after all, it is hard to classify this approach as another instance of Baudrillardian current of thought postulating new era of unconditional dissemination of signs and dissolution of any structure of meaning. Insofar the Essex School theory strongly draws on a reformulated Gramscian concept of hegemony, which is defined as a performative agency of ideological interventions that is capable of quilting contingent field of differences and providing precarious regularities of social order. The logic of hegemony, as articulated in Laclau and Mouffe's approach, should be then theorized as a strategy of decidability in the field of undecidability.

In their seminal Hegemony and Socialist Strategy Laclau and Mouffe (1985, p. 67-68) freed the concept of hegemony from economic and class reductionism through adoption of the discourse theory's assumptions to the essentialist Gramscian premises concerning class relations. The reworking of classical Gramscian theory in line of Derridian deconstruction led to the abolition of the transcendental center embodied by the category of privileged proletariat class and the principle of economic relations of production which would govern the objective course of history. Deconstructed concept of hegemony demonstrated that the process of social change is not managed by the objective rationality (e.g. essentialist "historical necessity"), which would pose an external and motionless instance above the language differences. As a result of this re-theoretization of Gramscian heritage social change was perceived as a articulatory practice that is open to all competing subjects which are capable of transcending their contingent particularity into the mythic order of universal significance (LACLAU; MOUFFE $p$. 178). Laclau (2005, p. 226) asserted that hegemonic articulation institutes a structure of meaning, which organizes social structure into complex of collective identities even though they do not manifest essentialist rationality. According to the Essex School's scholars this is the very performative act of naming that institutes the conditions of the possibility of hegemonic decision which lays surface for the inscription of social performances. Therefore theory of discourse directs attention toward the ideological mechanisms of constructing contingent foundations that organize regularities of social objectivity (LACLAU, 2005, p. 118).

Smith (1998, p. 93) keeping in line with Saussure's argument, which states that the significance is fixed by the arbitrary decision and not by its 
inherent essence (DE SAUSSURE 2002, p. 91-92) ${ }^{1}$, argued that the meaning of social structures, institutions and collective identities is always the result of a hegemonic decision, which is not determined by any essentialist agency preceding the negative field of discourse's differences. Any identity is thus a result of the practice of naming, that is, a performative act that reiterates the particular signifiers generating the broader field of ideological structure. Smith (1988, p. 92) claims that the state of "naturalness" of the ideological structure's meaning is a "normalizing" effect of particular hegemonic interventions, that is, performative procedure includes the mechanism of excluding the contingent traces of ideology's power relation, it erases opposing interpretative frameworks, hence the difficulty of grasping the moment of arbitrary hegemonic involvement. Additionally, it is important to recognize the mutual dependence of the ideological articulations and social practices. Performative self-reference reproduces its tautological effectiveness: the hegemonic ideology introduces certain social practices, which are reiterated and through this legitimize their ideological justification. Laclau (1990, p. 33-36) points out to an example of the collections of social practices and institutionalized discourses that make up the sedimented structures of former hegemonic interventions that are being governed by the iteration of performative rituals.

The concept of performativeness as the agency that constitutes naturalized social relations, social hierarchies, relations of power, which does not express any external rationality includes traits of Pascalian genealogy. Like Pascal in describing the paradox of the "mystical foundation" of law which required an act of faith was guided by the argument of Montaigne, similarly Althusser (1994, p. 127), and later Laclau and Mouffe followed

\footnotetext{
1 "The bond linking the signifiant and signifié is optional. In other words, because sign is understood as the whole implied by the association resulting from the signifiant signifié, we can say simply: the linguistic sign is arbitrary" (DE SAUSSURE, 2002, p. 91). De Saussure gives the example of the arbitrary character by using the word "la soeur" (sister), which - according to him - is not linked to any internal union of sounds, which are used to that concept as a signifiant, as well it could be presented by any other series of words. This is corroborated by the existence of the word "sister" in other languages (2002, p. 92).
} 
this path demonstrating the crucial agency of ideological performativity in achieving interpellation effectiveness of the Ideological State Apparatuses. The analogy with the Pascalian performative sources of the law's legitimacy may be traced in a broader context of the recent postmodern scholarship. Derrida, while referring to Pascalian thesis, pointed out that the legitimacy of the law involves a paradox: it is impossible to establish a foundation of law, its sources of authority are obscure, and thus Derrida concludes: the instance of the law's legitimacy is always performative, and it cannot be justified within its own logic, ultimately the exercise of law is based on the "trust" and "faith" (DERRIDA 1999, p. 29). Similar performative agency was revealed by Žižek in his analysis of religious practices. He carried out analysis using the example of the Pascalian concept of automaton related to the paradoxical logic of the obedience to the arbitrary instance of faith. According to Žižek (1989, p. 36-37) the reasons of faith are demonstrated only to those who had already believed. Believers as Žižek claims, believe not because they have found compelling reasons that corroborate their faith, but simply because they believe. Identical self-reproductive logic of the tautological faith was presented by James (2001, p. 338-339) in his criticism of the proofs of God's existence as articulated in scholastic philosophy. This argument - according to him - is persuasive only for those who had already believed in this evidence for other reasons. These other reasons James usually defines as "feelings", "emotions", "affect" (it is important to note that affect is internal and cannot be verified). Reasons of faith of this traditional approach should be deemed as a retroactive construct, which proves nothing, it only corroborates pre-existing belief (JAMES, 2001, p. 338-339). This pre-existing belief in fact, has little to do with codified religious beliefs but with the order of affect, which is radically negative and is irreducible to any positive substance. And this point brings us into the core of the School of Essex' s recent ontological developments. Firstly, I will present School's argument on ideological performativeness in the subject's constitution and secondly, this paper will focus on affective aspects of social ontology in Laclau and Mouffe's work. 


\section{Hegemony and ideological interpellation}

For Laclau and Mouffe the emergence of subjectivity is juxtaposed with the constitution of hegemonic ideology. Žižek (1999, p. 182-184) while describing the Essex School's concept of hegemony asserted that it corresponds to a basic model of ideological interpellation as defined by Althusser (1994, p. 128-130): social agents are identified with specific roles in the intersubjective network in a series of ideological procedures exercised by the Ideological State Apparatuses. Thus in both instances we face the similar result - the subject is constituted. Howarth and Stavrakakis (2000) after comparing two positions found that in Althusserian and Mouffe/Laclauian approaches the constituted subject is not a single, transparent to itself substance, it does not represent a self-rational entity. The ideologically interpellated identity is "mineralized" by an arbitrary act of signifier's intervention, what makes this externally constituted identity only temporarily fixed and precarious, and always open to new rearticulations (LACLAU, 1990, p. 39-41). Here, however, as Howarth and Stavrakakis continue, the similarity between two positions ends. Convergence in the critique of rational subjectivity cannot hide their divergent understanding of the functions of the ideological interpellation's agents.

For Althusser, remaining in the logic of orthodox Marxism, the state and its ideological articulations serve as the means of the reproduction of the dominant classes' power relations. Thus the existence of Ideological State Apparatuses functions as the instance reproducing the ideology of a privileged class, aiming to strengthen its economic interests (ALTHUSSER, 1994, p. 102-104). Quite opposite, for Laclau and Mouffe, the operation of ideology is not determined either by the position of class interests or any other pre-discursive factors, but by the contingent dynamics of hegemonic struggles. Ideological State Apparatuses should be thus perceived as scattered instances of ideological substance's transmission that is not developed in accordance with the objective logic leading to the accomplishment of any pre-established essence(e.g.relations of production), but it should be understood as a result of ideological self-reference, that is to say, performative reiteration of ideological construct. Ideological State Apparatuses act as the locus where the hegemonic structure of meaning is 
not assuming any telos, Ideological State Apparatuses provide merely the ideological conditions for the existence of hegemony itself.

Having outlined the peculiarity of the ideological performance in the Essex School's theory, at this point I have to link its function with the failed ontological position of the subject and symbolic order. The failed position should be perceived ultimately as the agency which triggers the dynamics of ideological interpellation, that is, the original lack that crosses subject and symbolic represents precisely what hegemonic practices are attempting to fill in. This feature also marks the fundamental departure of Laclau and Mouffe's approach from the Marxist tradition. According to Howarth and Stavrakakis (2000, p. 14) the mechanism of identifying social factors with a specific ideology is not conditioned by the positive impact of any structural conditions (e.g. relations of production) which forms collective identities, but it is precisely the lack that stands at the roots of any subjectivity which initiates the movement of hegemonic articulations formed in Ideological State Apparatuses.

Here the Essex School clearly draws on the Lacanian concept of subject and object defined as barred entities, which are never fully reconciled with themselves, and their failed ontological status requires continuous suturing of this "incompleteness" through ideological substitutes that postulate impossible total identity. Hence any hegemonic discourse represents as much as grand narrative what utopian false consciousness. It is particularly clear in Žižek's insight (1992, p. 10-12) showing that méconnaisance is a prerequisite for the effective constitution of the subject position, which represents the imaginary modus of existence in response to the traumatic experience of the impossibility of holding a stable identity. Ontologically failed subject can be founded only as "oversight", as a defensive ideological structure obscuring the real which interrupts the idea of any total identity, including the essentialist idea of the subject (LACAN, 1993, p. 39; ŽIŽEK, 2000, p. 119-120).

\section{The subject of lack and utopian narrative}

It is necessary to clarify the definitions of subject and object that are being used in the Essex School theory. Firstly, Laclau and Mouffe following 
the psychoanalytic tradition avoid placing a rigid boundary between symbolic order and subjectivity. As Laclau (2005, p. 52-53) stated in On the Populist Reason the contrast of individual and collective psychology loses its focus in light of Freud's psychology of the community, where it is stressed that the subject is invariably linked to the other, who is treated as a model, as an object, as an assistant, as an opponent (see Freud 1998: 53); thus Freudian individual psychology should be regarded at the same time as a social psychology. But the impossibility of grasping separation between subjectivity and objectivity has been clarified mainly in the Lacanian approach, whereby the split (barré) intersects the symbolic order and subjectivity. Hence according to this theory, the traditional concept of subjectivity, which sought self-identification of the subject with its own ego, loses its relevance (Lacan 1993: 80). In the Lacanian perspective it is impossible to reduce subjectivity to ego, which is deemed as a sedimented imaginative space of images that is being constructed by the subject about oneself usually during the period of early infancy (LACAN, 2004, p. 17). Lacan calls this period the "mirror stage", and before this stage is completed and the subject identifies himself with the fantasmatic ego, the infant experiences himself as being "fragmented", "inconsistent" (LACAN, 2004, p. 20).

Stavrakakis (1999, p. 18-19) indicates that the product of "mirror image" (narcissistic ego) does not lead to overcoming the alienation of the subjectivity. The ego does not integrate the order of the unconscious and libidinal drives, which still remaining outside the ego initiate the emerging experience of lack. The lack, which stands in the center of the subjectivity highlights the decentred nature of subjectivity which seeks to secure a stable ground in the symbolic order (STAVRAKAKIS, 1999, p. 18-19). The subject lacking positive identification is entering the symbolic network, which as Lacanian tradition assumes is equated with the order of signifier (expressing a radical inability to function as a stable representative of the significance). This point was succinctly put by Butler (1993, p. 191): "No signifier can be radically representative representation, for every signifier is the site of perpetual méconnaisance; it produces the expectation of a unity, a full and final recognition that can never be achieved". Failure to identify with the order of the signifier, triggers the process of incessant ideological constructs, and here we find the source of ideological méconnaissance. 
Concluding this aspect of performative function of ideology, it should be stated that effective ideological interpellation carried out by Ideological State Apparatuses precisely represents the act of suturing the lack in the symbolic order and instituting ideological méconnaisance, which implies the need for identification with the "external" narrative structures. This operation clearly recalls the effect of infant's identification with his mirror image as described by Lacan (LACAN, 2004, p. 3-9). The infant, which is a bundle of inconsistent drives, and uncoordinated movements, overcomes this troubling situation by identifying with his imaginary coherent external image in the mirror. Similarly the subject achieves consistent identification as a result of ideological interpellation (SMITH, 1994).

The (im)possibility of the fully constituted subject position, according to Laclau, indicates therefore a necessary utopian ideological component in the process of founding social objectivity, however not elaborated in terms of the traditional concept of false consciousness - but precisely in the reversed interpretation of the Marxist orthodoxy (LACLAU, 1990, p. 92). Ideological false consciousness does not mean misrecognition of the positive essence - but as Laclau explains - something quite opposite: "it would consist of the non-recognition of the precarious character of any positivity" (LACLAU, 1990, p. 92). Ideological false consciousness fulfills a paradoxically productive function, it allows the formation of discursive practices, despite the impossibility of closure of a set of meaning in a field of language (LACLAU, 1990, p. 92). Performative ideology represents the mythical modus of being that includes in itself a negation of contingency:

"The ideological would be the will to 'totality' of any totalizing discourse. And insofar as the social is impossible without some fixation of meaning, without the discourse of closure, the ideological must be seen as constitutive of the social. The social only exists as the vain attempt to institute the impossible object: society. Utopia is the essence of any communication and social practice" (LACLAU, 1990, p. 92). 


\section{Mapping affective turn in late modern era}

Summing up the current argument on the intertwine of performativity and affectivity in the Essex School's scholarship we obtain the following conclusions.

Firstly, the emergence of hegemonic formation is possible insofar as an ideological construct have managed to transcendent its particularity into an order of universality, or to put it in other words: signifiers have been transformed to a totalizing horizon of discourse, that contributed to the constitution of hegemonic collective will. Laclau (2005, p. 110) notes, however, that the fluidity of transition between the stages in the shaping of hegemonic formation is not founded merely on logical, linguistic or dialectical instances, its cohesion can not be reduced to the symbolic identification of linguistic elements. The recent developments in the Essex School's scholarship emphasize that the proper analysis of hegemonic formation must take into account the contribution of the affective agency incarnated in the performative practices of naming. To obtain an ontological coherence the hegemonic formation needs the intervention of a new quality. This new quality - as Laclau continues (ibid) - should be inferred from the libidinal order which guarantees that a particular signifier is invested with the affective component of the (im)possible social totality. A necessary complement to the process of manufacturing a hegemonic formation comprises, therefore, the act of cathexis, which is inseparable from the act of naming. Collective objectivity is constituted through the practice of naming - a performative act of repeating certain signifiers, which generates an ideological structure. However, as Laclau adds, the act of naming cannot be limited merely to the textual performativeness. A signifier is supplemented with the invisible added value, it is inseparably embedded in the dynamics of the performativity of language.

There is no possibility of a language in which the value relations would be established only between formally specifiable units. So affect is required if signification is going to be possible. [...] Affect is not something which exists on its own, independently of language; it constitutes itself only through the differential cathexes of 
a signifying chain. This is exactly what 'investment' means.[...] So we can conclude that any social whole results from an indissociable articulation between signifying and affective dimensions (LACLAU, 2005, p. 111).

This affective aspect of the social ontology that marks the Essex School theory's recent advancement is developed within the framework of crucial Lacanian concept objet petit $a$, which is defined as a substance that exceeds the object itself, that does not have any positive substance but it represents a crucial libidinal agency maintaining the ontological coherency of the object in all contrafactive situations (ŽIŽEK, 1989, p. 89-97). Objet petit $a$ - in Lacanian psychoanalysis - is a remnant of the primordial exclusion of pre-symbolic undifferentiated reality identified by Lacan with the unseparated dyad of the mother and infant. Žižek (2000a, p. 257) explains that primordial exclusion (Intervention of the Name of Father), which separates mother and child constitutes, on the one hand, the ontologically failed subjectivity ${ }^{2}$, but this primordial separation brings about also symbolic order, insofar as it creates the empty space of the universality ${ }^{3}$ and objet petit $a$. Objet petit $a$ is a trace of the unity of the mother-child before the emergence of the subject in the symbolic order governed by signifier, it acts as a phantasmatic partner that runs the desire for the restitution of the object unmediated in language (ŽIŽEK, 2000a, p. 257). Hence it might be asserted that objet petit a functions as a kind of magnet that aggregates scattered elements of reality in the illusion of full undivided reality and produces this way a phantasmatic effect of méconnaissance. Here it becomes clear that objet petit a functions as the missing transcendental signified. Thus according to Žižek (2001, p. 66) it brings an effect of imaginary wholeness within the subjects's internal libidinal logic where the reality achieves the sense of the coherent whole.

The implementation of the insights on affective order into the discourse theory leads to new appropriations of the function of positive

\footnotetext{
2 The body is split into the ego and the unconscious.

${ }^{3}$ Therefore particular ideological signifiers are able to struggle to fill in this empty place while postulating hegemonic proposals.
} 
content in the hegemonic ideological narrative. The theorizing on the invisible objet petit $a$ that organizes coherence of hegemonic structure shows clearly that, the core of hegemony is not grounded in the particular content that might be reduced to positive assumptions, it does not involve any reference to well defined ideological persuasions, because the involvement of objet petit a does not diminish the scale (order of magnitude) or the intensity of a particular language game's performativity. Smith (1998) rightly noted that Laclau and Mouffe's approach mirrors in many ways Derrida's elaborations on the crucial role of longing for the justice. This is the very desire for justice which blocks the movement of deconstruction, not the positive ideal of justice, whatever its normative shape might be (IDZIAK, 2008).

There are also other fields where Derridian approach implicitly indicates the crucial agency of negativity that brings together the positive field of significance, e.g., it is particularly vivid when Derrida in his analysis of two sources of religion points to "an excess of life", to an invisible substance "which is more valuable than life itself". Following Heideggerian insights Derrida asserts that primordial immunity of the community is linked with the sense of holiness (Heilig), community resists spoilness because it contains an excess of elusive sense of "wholeness" (DERRIDA, 1999, p. 75-77). Community is able to maintain "its idiom, culture, identity, body," insofar as it stands in the name of "what is more valuable than community itself” (DERRIDA, 1999, p. 75). This spectral category - Derrida notes - keeps the community alive and also opens it to "something greater than itself" (DERRIDA, 1999, p. 76-77). In effort to grasp this elusive substance, which clearly mirrors Lacanian objet petit $a$ ("health", "wholeness") Derrida also points to another aspect of the community's immunity - the ability of exerting power what - we might add - corresponds to the hegemonic logic which is always underpinned by the relations of power: "It seems like an effort to uproot the uprootedness and return to appropriate intact and untouched sacredness of life "(DERRIDA, 1999, p. 79). The similarities with Laclau's theory are striking: an excessive negativity introduces the movement of ideological méconnaissance aiming at the restitution of the unspoiled "lost object". Also similarly like Derridian negative desire for justice, Laclau in On Populist Reason carefully separated 
the contingent symbolic content (e.g. ideological assumptions, narrative ideals) from the undeconstructed negative libidinal force that invests in particular frameworks of positive significance.

The advent of affective dimension in the Essex School's theory might profoundly rearticulate famous thesis on the end of grand narratives in the late modern context of the emancipation ideologies' demise (LYOTARD, 1979). Laclau's contribution sheds new light on this problem while it suggests that affective order meshed in performativity of ideological practices does not point out to the collapse of the grand narratives but it decisively institutes a split between the stable relationship of the narrative's structures and contingent content these structures embrace. Thus Laclau's elaboration is not particularly concerned with the demise of the grand narrative, it rather shifts the core of the analysis into structural considerations mapping the agency of the universality that is produced as the effect of libidinal investment in signifiers. This affective transformation of particular signifiers into mythical totality of meaning that cannot be reduced to any positive value introduces a ideological méconnaissance which is a necessary component for the constitution of social field. Libidinal investment in the practice of naming distinguishes Laclau's concept from the pure play of language differences that stand in the center of Lyotard's theory. Lyotard assumes that contemporary social field is permeated by small narratives, but from Laclauian perspective - small narratives by definition are grand narratives. Therefore even expert narratives, which according to Lyotard have eliminated grand emancipatory ideologies, should be considered as grand narratives because they all lead to the effect of hegemonic decision underpinned by affective order. By contrast to the assumptions of discursive idealists, the Essex School position shows that the strength of the hegemonic narrative is not founded in its positive diagnosis - this sort of narrative does not refer to any external criteria deciding which symbolic substance is legitimate. Its decidability is not determined by topography, or any positive principle (e.g. Enlightenment ideology of progress) that would occupy external position to hegemonic decidability - but its effectiveness is set by an act of naming, which is based on articulations, irreducible to a specific location and objective principles expressed in a particular narrative (LACLAU, 2000a, p. 283). The irreducibility of affectivity in hegemonic 
practices to external principles is analogous to the incommensurability of salvation, of which James (2001, p. 188) wrote: "Salvation of the little man is for himself [emphasis in original] always great salvation and it is the greatest of all events."

The agency of affectivity renders positive meaning of the hegemonic formations contingent, however, simultaneously necessary: the collective identities are always determined retroactively. The hegemonic formation does not express a prior identity before its emergence, its meaning is constituted as the act of retroactive reference to itself (LACLAU, 2005, p. 104). Affective naming becomes the ground of the unity of the objects and this procedure "is not subordinated either to description or to a preceding designation" (ibid).

Of course, this mechanism interrupts diagnosed linear order of the time (as it recognizes the interpretation of classical logic, in which the outcome is the result of reason and not vice-versa). In respect to this reversal logic the Essex School position follows Lacanian psychoanalytic tradition, which categories, as Laclau asserts, belong to the field of social ontology. According to Lacan the meaning of the first word in a sentence can be determined only after reading or hearing the last word in sequence, therefore the significance of the sentence is constructed retroactively by the confrontation with the semantic context provided by the entire statement (FINK, 1995, p. 63). Meaning is not an "instant substance" but a historical construct ex post. This specific logic of deference in the construction of meaning - according to Fink - is exposed already in Freudian legacy. Freud introducing the category of deferred action (Nachtraglichkeit) noted that the first event for the subject does not generate meaning, which "remains undetected" until the second event comes (FINK, 1995, p. 64). Only retroactively overlooked the first event is marked as a trauma. And as Fink explains: the meaning of the first event (the cause of classical logic) depends on the impact of the second event (the effect of classical logic), and inversion occurs: the effect becomes the cause and the cause functions as the effect. Lacan asserted that overlooked first event is a Master Signifier, nonsensical signifier (S1) as much irrelevant and remaining without a semantic relation to the forthcoming signifier (S2), as necessary in its structural arbitrary position (identified with traumatic intervention 
of the Name of the Father) for the constitution of the structure of meaning (FINK, 1995, p. 130-131; p. 75-76). In line with this assumption, this is the secondary signifier (S2), that represents meaning for the nonsensical S1, since it retroactively institutes meaning for the primordial trauma that was devoid of positive content (FINK, 1995, p. 75-76).

The interactions between S1 and S2 represents the logic of empty signifier in Laclau's theory. The signifier without the signified which marks an empty place in signifying structure is completely unrepresentable, however, at the same time it serves as a necessary instance that initiates the unity of "a given experience of meaning". Empty signifier is able to perform this function because of its ability to act as a medium that embodies object petit $a$, which constitutes the crucial agency of naming. This is the moment when partial signifier takes up the shape of "a universality with which it is incommensurable" (LACLAU, 2005, p. 106), and this moment represents clearly a hegemonic relation when a particularity assumes the role of impossible universality. Laclau claims that: "No social fullness is achievable except through hegemony; and hegemony is nothing more than the investment, in partial object, of a fullness which will always evade us because it is purely mythical" (2005, p. 116). And later he adds the concluding point about the function of empty signifiers in interaction between naming and affective agency:

Embodying something can only mean giving a name to what is being embodied; but since what is embodied is an impossible fullness, something which has no independent consistency of its own, the 'embodying' entity becomes the full object of the cathectic investment. The embodying object is thus the ultimate horizon of what is achievable - not because there is an unachievable beyond, but because that beyond, having no entity of its own, can be present only as the phantasmatic excess of an object through which satisfaction is achievable (LACLAU, 2005, p. 119).

At this concluding point we see a twofold feature of cathexis and performativity when a partial signifier has become a name of the mythical lacking fullness. Only when cathected names have been transformed into 
a horizon of hegemonic field signifiers have been freed from the specific positive content (LACLAU, 2005, p. 117-120). Through this operation empty signifiers were able to act as a locus of objet petit $a$ for the binding of the variety of particular elements in the hegemonic formation. Only within the perspective of affectivity hegemonic formation could be termed a historical singularity, because, as Laclau (LACLAU, 2005, p. 118; p. 183) explains, there is no conceptual correlate, for which libidinal act could have related to, thus any social formation is not expressing any preexisting essence, even though retroactively it uses historically available ideological substance.

\section{Bibliography}

ALTHUSSER, L. For Marx. London: Allen Lane, 1969.

Ideology and Ideological State Apparatuses (Notes towards an Investigation)", in: Žižek, S. (Org.) Mapping Ideology, London, 1994.

BUTLER, J. Bodies that Matter: On the Discursive Limits of Sex, New York: Routledge, 1993.

DERRIDA, J. Politiques de l'amitié, Paris: Galilée, 1994. . Acts of Religion. New York: Routledge, 2001. . Wiara i wiedza, In: DERRIDA, J.; VATTIMO, G. (Org.). Religia.

Warszawa: Wydawnictwo KR, 1999.

FINK, B. The Lacanian Subject: Between Language and Jouissance, New Jersey: Princeton University Press, 1995.

FREUD, S. Psychologia zbiorowości i analiza Ja. In: RESZKE, R. (Org.). Sigmund Freud. Pisma Społeczne. Warszawa: Wydawnictwo KR, 1998.

HJELMSLEV, L. Resume of Theory of Language. red. i thum. na angielski Whitfield, F., Copenhagen, 1975.

HOWARTH, D. Discourse. Buckingham: The Open University Press, 2000 .

; STAVRAKAKIS, Y. Introducing Discourse Theory and Political .; NORVAL, A.; STAVRAKAKIS, Y. (Org.). Discourse 
Theory and Political Analysis: Identities, Hegemonies and social Change. Manchester: Manchester University Press, 2000.

IDZIAK, U. Doświadczenie Wiary jako Margines Filozofii, unpublished $\mathrm{Ph}$.D. dissertation, Institute of Philosophy and Sociology, Polish Academy of Sciences, 2008.

LACAN, J. The Seminar. Book III. The Psychoses, 1955-1956, London: Routledge, 1993.

. Ecrits. New York: Norton, 2004.

LACLAU, E. New Reflections on the Revolution of Our Time. London: Verso, 1990.

. Foreword. In: ; NORVAL, A., STAVRAKAKIS, Y.

Discourse Theory and Political Analysis: Identities, Hegemonies and Social Change. Manchester: Manchester University Press, 2000.

. Constructing Universality. In: BUTLER, J., LACLAU, E., ŽIŽEK, S. (Org.). Contingency, Hegemony, Universality: Contemporary Dialogues on the Left. London: Verso, 2000a. . On populist Reason. London: Verso, 2005.

., MOUFFE, C. Hegemony and Socialist Strategy: Towards a Radical Democratic Politics. London: Verso, 1985.

LYOTARD, J. La Condition Postmoderne: Rapport sur le Savoir. Paris: E' ditions de Minuit, 1979.

MARCHART, O. Post-Foundational Political Thought. Edinburgh: Edinburgh University Press, 2007.

SAUSSURE, F. De. Kurs językoznawstwa ogólnego. Warszawa: Wydawnictwo KR, 2002.

SMITH, A. New Right Discourse on Race and Sexuality: Britain, 19681990, Cambridge: Cambridge University Press, 1994.

. Laclau and Mouffe: The Radical Democratic Imaginary. New York; Routledge, 1998.

STAVRAKAKIS, Y. Lacan and Political. London; New York: Routledge, 1999. 
ŽIŽEK, S. The Sublime Object of Ideology. London: Verso, 1989. . Enjoy your Symptom!: Jacques Lacan in Hollywood and Out. New York: Routledge, 1992.

. The Ticklish Subject: The Absent Centre of Political Ontology. London: Verso, 1999.

. Class Struggle or Postmodernism? Yeas Please! In: BUTLER, J.; LACLAU, E.; ŽIŽEK, S. (Org.). Contingency, Hegemony, Universality: Contemporary Dialogues on the Left, London: Verso, 2000.

. Holding the Place. In: BUTLER, J.; LACLAU, E.; ŽIŽEK, S. (Org.). Contingency, Hegemony, Universality: Contemporary Dialogues on the Left, London: Verso, 2000a.

. Przekleństwo fantazji. Wrocław: Wydawnictwo Uniwersytetu Wrocławskiego, 2001.

Data de Registro: 09/09/2010

Data de aceite: 20/10/2010 